\title{
EFFECT OF MIDWIFERY CARE EDUCATION ON NEONATAL CARE KNOWLEDGE AND PRACTICE AMONG MOTHERS
}

\author{
Septiana Juwita \\ School of Health Sciences Widyagama Husada, Malang
}

\begin{abstract}
Background: The first 28 days or 4 weeks of life after birth is known as neonatal period. Care during neonatal period is of immense importance for the proper development and healthy life of a newborn baby. It is a period in which majority of infant deaths occur. During this period, a newborn has about 15 times greater risk of developing diseases and death than any other time before birth. This study aimed to determine the effect of midwifery care education on neonatal care knowledge and practice among mothers.
\end{abstract}

Subjects and Method: This was a quasi-experiment conducted at Mojolangu community health center, Malang. A total sample of 50 mothers was selected for this study and measured before and after midwifery health education. The dependent variables were neonatal care knowledge and practice. The independent variable was midwifery care education, by providing training education such as: bathing babies, giving clothes to babies, cleaning defecation, urinating babies, and maintaining the cleanliness of baby's skin. The data were obtained from questionnaire and direct observation. The scores of knowledge and practice before and after education were tested by $t$ test.

Results: Midwifery knowledge after education (Mean= 72; $\mathrm{SD}=14$ ) was higher than before education (Mean $=51 ; \mathrm{SD}=9)$, and it was statistically significant $(\mathrm{p}=0.008)$. Midwifery practice after education (Mean $=78 ; \mathrm{SD}=15)$ was higher than before education (Mean $=57 ; \mathrm{SD}=12)$, and it was statistically significant $(\mathrm{p}=0.002)$.

Conclusion: Midwifery care education increases neonatal care knowledge and practice among mothers.

Keywords: midwifery care, health education, knowledge, practice, neonatus, mothers

\section{Correspondence:}

Septiana Juwita. School of Health Sciences Widyagama Husada, Malang, East Java. Email: septiana.juwita@gmail.com. Mobile: 085725445017.

The $5^{\text {th }}$ International Conference on Public Health

Best Western Premier Hotel, Solo, Indonesia, February 13-14, 2019 | 251

https://doi.org/10.26911/theicph.2019.03.03 